\title{
Training: a special form of teaching
}

\author{
Eckhard Meinberg \\ German Sport University Cologne \\ Germany
}

\begin{abstract}
This article pursues two objectives: in the first place I want to show to what extent coaching in action is a special form of teaching, i.e. that it is a genuinely pedagogical process. I propose to do this by portraying teaching as a complex action which is characterised by a set of definite basic operations like showing, diagnosing, anticipating, interpreting and many more In addition I want to pay tribute to the temporal constitution of training by looking at it from the aspect of articulation, show the interrelation between training and educating and underline the fostering of talent as a task that teaching and training have in common. At the end I want to discuss the moral dimension of coaching. All of this makes it possible to proceed with the article's second aim which is to establish a connection to the current international discourse about teacher professionalism which then will be transferred to the professionalisation of coach-action.
\end{abstract}

Key Words: Teaching, learning, coaching, competence, moral/ ethics.

\section{RESUMO}

Treino: uma forma especial de ensino

Este artigo persegue dois objectivos: em primeiro lugar quero mostrar até que ponto a intervenção do treinador é uma forma especial de ensino, isto é, que se trata de um processo genuinamente pedagógico. Proponho fazer isto retratando o ensino como um processo complexo, que é caracterizado por um conjunto de operações básicas como a demonstração, a antecipação, a interpretação e muitas outras.

Complementarmente, quero valorizar a estrutura temporal do treino, percebendo-a a partir da necessidade de articulação, mostrar a interrelação entre o treino e a educação e sublinhar a importância da promoção de talentos como uma tarefa que o ensino e o treino têm em comum. Finalmente, quero discutir a dimensão moral da acção do treinador. Tudo isto torna possível avançar para o segundo objectivo deste artigo, que é estabelecer uma relação com o discurso corrente no plano internacional acerca do profissionalismo do professor, o qual então será transferido para a profissionalização da acção do treinador.

Palavras-chave: Ensino, aprendizagem, treino, competência, moral/ética. 


\section{INTRODUCTION}

Since there was competitive sport there have been coaches. The origins of systematic coaching can be traced back to the ancient world. Less in gymnastics than in athletics coaches were in demand early on, especially where people struggled for fame and sporting honour on the occasion of the Olympic Games or the (pythic and isthmic Games). Back then some coaches gained in prestige enormously when their athletes happened to be successful so that the antiquity already had its FERGUSONs, HITZFELDs or CRUFFs. But many centuries had to pass before this profession was able to gain acceptance and before -thanks to the support of the media- it was able to make some coaches famous. Those coaches enjoyed a kind of fame that usually only the athletes themselves or actors or maybe politicians are expected to get. Back in the ancient times you couldn't have foreseen that so-called world-class coaches would one day achieve the status of cult figures, that people would make icons out of them as they are doing today. Coaching itself may be old (1) yet as a profession it is extremely young and it profits from the enormous and unstoppable rise of sport and the gaining popularity of a sporting style of living. It is a fact that the activity of coaches in the Western industrialised countries isn't confined to the institutionalised sport in clubs and associations. In these rich countries where certain "classes" (BOURDIEU) set great store by their health and well-being an increasing number of "wellness-coaches" are able to earn their living by this occupation. But also highly rated men of industry and commerce treat themselves with their "personal-trainer", who watches over the wellbeing of his clients. The "body boom" provides coaches with totally new job prospects outside the traditional sport business. At the time the "body boom" seems to correspond to a "trainer boom". Admittedly, this article exclusively deals with the "classic" coach of clubs and associations, i.e. the kind of coaches who should they be able to walk off with enormous success often are the number one topic of the media. But if you're looking closely at how coaching developed into a new profession in the modern age you cannot fail to realise that it is still on its way towards a genuine professionalisation/ professionalism. According to the theory of professionalisation/professionalism the status of coaches isn't secured yet and the fact that there are highly successful professional coaches basking themselves in the limelight is no contradiction to that. This article doesn't want to deal with the coaches' recipes for success, which sometimes are being cherished like life itself, although this would be both possible and fruitful, what it sets out to deal with is the coaching-profession and its professionalism by showing aspects that have been neglected up to now, it wants to pave the way for future research. What this article centres on is to prove that coaching is a special form of teaching. But not only that: The thesis above can be strengthened by the fact that coaching is instructive and didactic at its core. Before I can give a selective yet substantial answer to the question why coaching is a form of teaching I have to give you an idea of the requirements and demands that are surrounding this activity. In other words: I want to put the performance profile of coaching for your inspection.

\section{COACHING AS A COMPLEX CHALLENGE}

Professional coaching is an extremely demanding activity and occupation that requires versatility, which you can see clearly when looking at the activities of national coaches. HOLZ has given an elaborated outline of this: " in principle you can differentiate between eight fields of activities with their corresponding tasks:

- Planning, carrying out, managing and controlling training - and competition processes

- Advice, counselling, care, help

- Co-ordination/ management

- Organisation

- Evaluation/ analysis

- Public relations

- Further vocational training, continuation of one's education

- Teaching, research $(2,10)$

Obviously, this occupation includes extremely complex spheres which go far beyond the actual training process.

Beside the training process itself the coach has to manage a multitude of tasks and accordingly he has 
to be competent in many different spheres. Today, one area of competence seems to get increasingly important and that is the kind of competence you need when dealing with the media. This "mediacompetence" seems to be coming to the fore more and more. Especially coaches who are working on a high performance level with their athletes and who are in the centre of public interest (e.g. soccer coaches) are expected to be able to cope with the media in an appropriate way. This means that they have to acquire a kind of competence they haven't been or at least not sufficiently been trained in. In the meantime what seems quite remarkable is the rapid specialisation of this profession, which is also typical of a lot of other occupations today. What is behind this is the belief that such a specialisation of coaches will have a positive effect on the athletes' performances. Nowadays it seems to be en vogue among professional coaches that the head coach, who carries the main responsibility for the planning and carrying-out of the training, surrounds himself with special coaches for fitness-training and goal keeping, who recently have been joined by mental coaches who are paying tribute to the motto that the decision over win or defeat is already being done in the mind. You can see that the trend moves away from the soloist towards a whole team of coaches. Here, you can observe an ambivalent process:

On the one hand complexity is being reduced but on the other hand it is being increased. In our example the increase in complexity lies less in the training itself, i.e. the training in the narrower sense, the carrying out of the training, than on the social-communicational level. The complexity lies in the relation between people. As a rule you lead a team of coaches in a different way than you lead a team of athletes.

In the following I want to concentrate on training in the narrower sense, which is a special form of teaching. In order to be able to prove this I want to offer you some clear-cut clues by presenting a brief and shortened phenomenology of coaching. When you devote some time on thinking about the teachingprocess you cannot fail to realise that teaching is an extremely complex activity and that it consists of a number of different forms of actions.

\section{TEACHING AS MULTI-FORMED ACTION}

As soon as you start dissecting teaching you'll immediately discover a multitude of tasks which make up this practice. When somebody is teachingand a coach is doing that same thing- then he's carrying out a number of basic operations which make up teaching. Of those I only want to mention a few of the most important ones: Even if at first you'll hesitate to describe training in the narrower sense as a form of teaching without doubt you'll still be content to describe it as a special form of instruction, which has many parallels to the teaching done in school, but which differs considerably from physical education in school in some respects: Voluntariness, exterior basic conditions and performance level. Nevertheless, there cannot be any doubt that training is indeed a specific teaching situation because it is about imparting something - a subject- to somebody, e.g. enabling somebody to do the overhand pass in volleyball. In short this is the typical basic concept of teaching: Somebody who is competent in sth. (=coach/teacher) teaches a subject to the ones less competent than him (=athletes, pupils, learners). Since ROUSSEAU at the latest people have described this procedure as the pedagogical triangle. Who would honestly be able to substantiate that training isn't about a typical teaching and learning process, an equivalent to teaching and learning? The coach teaches in order to make the athletes learn something. This way teaching can be defined as a supportive action for learning. Learning and teaching turn out to be two sides to the same thing. To put it in rather more concrete words: Which actions have to be performed so that learning can take place? Above all: showing or pointing at st. Somebody teaching at the same time always shows something by pointing at a subject or the learners. The teacher chooses something from a whole range of possibilities, e.g. the learner's jumping behaviour at the net while doing the overhand pass. When the player is making a mistake, the coach corrects him by pointing at the player and by showing him how to correct his mistakes. But: The coach isn't just pointing at a subject or a player, no: $\mathrm{He}$ is also showing something of himself as a person, of his commitment, his temperament, his feelings and so on. He is exposing himself to a certain degree, he is 
revealing himself as a specific personality, which is why this act of showing or pointing at something as a basic process of learning has three different elements as point of reference: Firstly the subject, secondly the athletes and thirdly the teacher himself, i.e. the coach.

Unmistakably, other activities are closely connected with this act of showing at the same time, activities which make up teaching and which training does also consist of. One of those you simply cannot do without is verbalising. A person who is showing something doesn't remain in a silent gesture, quite the reverse, he is talking because he wants to explain something. That is the reason why showing doesn't happen just for its own sake. The motivation behind showing rather is the attempt to explain something and this explanatory showing is fitted into various interpretations. Interpreting is aimed at making something comprehensible, the motivating force behind it is understanding.

Comprehensibility is the primary principle behind all systematic teaching and it has speech and speaking as its deciding medium, which in turn is determined by acts of interpreting.

Training as a special form of teaching is no exception to this, it affirms it. When coach and team come together in a meeting after training or before the beginning of a competition to discuss or fix their tactic line of approach the coach presents and explains his tactical approach by drawing the play system on a board and by pointing at some of the athletes in order to interpret their play behaviour with the help of anticipation.

With that, another basic activity is coming to light: anticipating. Anticipating undoubtedly means forging links between the past and the future. Coaches practice foreseeing things, they practice anticipating coming events - the more they are able to anticipate the better will be their team's prospects of success. Anticipating is so fundamental that it projects into other elementary activities. Even diagnosing, who serves to take stock, often contains anticipatory moments, which are transferred into a prognosis. A coach diagnoses his team's state of mind and body, and with the help of anticipation he tries his hand at a prognosis for the next game. Anticipating as a primary operation of teaching and training points to the temporal dimensions of teaching. When anticipating you're trying to take a look into the future but in a way that both the present and the past are involved: The actual act of anticipation takes place in the present, but in order to be able to anticipate you have to include the past into your considerations. All the dimensions of time pervade teaching and the same is true for training. It is one of the shortcomings of an elaborate theory of training that until now it still hasn't properly considered this phenomenon of time. Sport science as a whole hasn't really spend enough time on time. In the following I want to outline one main thought about time that is relevant to teaching.

\section{THE TEMPORAL ASPECT: THE ARTICULATION OF TRAINING}

Training as a special form of training is -like all other human activity- subject to the dimensions of time. Although there is compulsory school attendance, which is the price our society has to pay for the modernisation of our world, fortunately there is no such thing as compulsory training attendance. However: The one who attends training on his own free will necessarily needs and uses up time. Depending on the ambitions of the athletes they'll devote more or less time to their training.

Furthermore: The one who is working as a coach in a professional way is forced to use his time efficiently to get the most out of time.

Included in that is the ability to plan and organise. In the modern and hectic training business of today something that I want to call "time competence" is in demand more or less. Included is also that coaches must be able to organise training in single units. Following the terminology of modern didactics you could introduce the term articulation, which expresses the temporal structure of the training process-and this in two different constellations. It includes firstly the following sequence: 1 . Beginning, 2. broadening of the horizon and making possible new ways of learning, 3. repeating/ exercising and 4.creating possibilities for further learning. In addition, part of articulation is also the temporal sequence of the following phases: preparation of training, carrying out of training and evaluation. There's no room in this article for pursuing the idea of the articulation of training any further or in more 
detail, I only want to stress one aspect which is connected with the basic operations which are characteristic of teaching.

What I'm talking about here is the observation that a coach has to perform different operations in different training phases. During the preparatory phase of training much attention is directed towards planning, which includes anticipating, but also interpretations are not being neglected while communication is of no or little importance. Major activities of the phase in which training is actually being carried out are: showing something, explaining, presenting and establishing contact with the athletes. Here, leading and guiding come to the fore, which are of no importance at all during the preparatory phase. The evaluation phase is occupied with evaluating, reconsidering, interpreting and analysing, i.e. operations which all leave their mark on teaching practice. Though they are also present in other "articulation phases" during the evaluation phase they are of the greatest significance and they lend plausibility to the thesis that individual activities are emphasised differently in different phases of training. At the same time this confirms time to be an irreplaceable instrument for managing the training, a fact that finds its obvious expression in the articulation of training.

It is one of the certainties of professional teaching that it doesn't go off in a uniform way but that it varies according to external basic conditions and the personality of the teacher. Teaching is a deeply individual activity, each teacher develops his own personal style: a unique form of teaching which is not exchangeable and which is dependent on many different factors. On the analogy of the teaching style, in which at the same time both knowledge and ability find their expression, with regard to training we can talk about a training style. In this training style the didactic character of training becomes evident.

\section{THE TRAINING STYLE}

In my view, a pedagogical theory of training which is at the same time structured in a logical way, rich in empirical content and which goes beyond a mere collection of remedies but does justice to the complexity of training is nowhere in sight yet. For somebody interested in developing such a theory an important task would be to take a close look at the communicative level of training, to examine how this level reveals itself in the relations and cooperations between coach and athletes and also between coach and coach. The research of training styles is still in its very initial stages. If it appears at all it will import results from educational science and results from research about teaching styles, as you can see in the LENK's works on training. LENK, a professor of philosophy, Olympic medallist and successful rowing coach, propagates the democratic and autocratic style of teaching, which we know from educational science and consistently he talks about a democratic and an autocratic training (5). While the democratic training backs up the autonomous athlete the autocratic training puts more emphasis on the heteronomous athlete. LENK sides with the democratic training, taking the model of the "mature athlete" as a point of reference. Of special importance is: The way in which single elements of training practice make up a specific training style refers to a specific orientation towards different images of man. LENK decides in favour of the old European educational idea of maturity, which he recommends as a central idea of a humane training. In addition, at least two more images of man have a part to play in the difference between democratic and autocratic training, which haven't been mentioned by LENK, but which preserve "classic" images of man of the modern times: On the one hand an optimistic one, which stresses autonomy and freedom of man and which forms the latent anthropological base for the democratic training, and on the other hand a pessimistic image, which lays more emphasis on heteronomy and lack of freedom and which lays the anthropological foundations for the autocratic training. While the optimistic image of man had a vehement advocate in ROUSSEAU, it was HOBBES that championed the pessimistic one. This "memory" or "remembrance" left aside, I only wanted to briefly mention that, obviously, training styles cannot do without basic points of reference. Images of man can serve as such points of reference. This is why training styles can be traced back to certain images of man, which exert an influence on a coach's actions that though it might be latent still cannot be put aside. 
Another observation closely connected with the above is as follows: The differentiation in democratic and autocratic training has its origins in the coach's management style. Different kinds of styles could induce a typology of trainers, which would contain each coach's individual characteristics, his "personal touch". The "democratic coach" as well as the "autocratic coach" would be two counterpoles on a "coach range", which would help to get information about the way the profession of coaches sees itself. In addition, we can also observe that the training style is almost as complex as teaching itself as there are quite a few factors which have an effect on this style. On the one hand there are external factors, e.g. the institutions a coach works for. Such institutions like e.g. traditional sports clubs engender a special atmosphere, which is largely determined by conventions, in which an unwritten code for the institution's attitude towards a coach is included. Some clubs let their coaches work in peace, they "give them their head" and do not want to reap the fruits of their coaches' industry immediately. Others exert pressure on their coaches, who are more or less forced to be successful, which in turn might have an effect on the training style.

Beside these external factors, you can also find internal ones, which concern the coach as a person, the way he sees his personality and his identity, his emotions, knowledge, mentality, the way he perceives the world around him and so on. Accordingly, the training style cannot be reduced to a purely methodical, technological sector. In the end the style is deeply rooted in the way a coach sees his own self and therefore also shows moral qualities which I will go into at the end of my paper. At this point I only want to indicate that the teaching style has found its counterpart in the training style, which again proves the didactic character of training.

\section{TRAINING AND EDUCATING}

Training as a special form of teaching is closely related to education without merging with it. What unites teaching and educating is the modified didactic triangle. Because of this triangle there is a correspondence between educating and teaching: Educating is made of the following components: somebody more competent in sth. (educator), some- body less competent (person that is being educated) and a subject as the objective of the educating process, which as a rule consists of a great number of different values.

There are indeed situations where the coach is "all" educationalist intending to influence his athletes' attitudes for purely educational reasons in order to improve their behaviour: Whenever he purposefully applies sanctions, whenever he admonishes, reprimands, criticises or threatens somebody - and vice versa whenever he encourages positive behaviour by praise. Indeed: The every day life of training is full of possible causes for education and educational effects. Training situations may turn into educationally relevant ones anytime: a training situation may sometimes take the form of an educational process and neither coach nor athlete may necessarily be aware of this.

An educational context like that may be planned and used with intention but then again this doesn't always have to be the case. For the training can have latent educational effects without the coach intending it to. A casual or accidental action, e.g. an exhortation coming from the coach directed at his protégé may well be of educational importance. It is perfectly conceivable and also realistic that coaches cause pedagogical effects in their athletes they never intended to. The opposite is also possible: A coach may have the firm intention to influence a situation in an educational way and all his intentions will fall flat, they won't have any effect whatsoever however hard he may struggle away.

What you can learn from this: Only on the condition that athletes are ready to go along with their coaches' educational ambitions, pedagogical effects may indeed occur. As soon as the athlete's will to let himself be educated is lacking, all the coach's intentions, however honestly they may be meant, will be clutching at thin air. To make a general principle out of this: As soon as the coach's educational ability won't meet the athlete's will, fruitful educational situations cannot take place. To actually be able to do educationally effective work the coach is depending on the cooperation with his protégés, once they refuse all the coach's attempts will remain futile. We can see that during training both intentional and unintentional educational influence is possible. One 
influence that is more unconscious and stays under the surface is something you may call the "hidden curriculum" of training. This hidden curriculum describes the structures training takes place in, which are not made public but which are more or less being taken for granted. These structures are being protected and supported by typical values, which cannot be given up. In training people may and will internalise some of these latent values, e.g. the athletes learn that work and effort will pay, that they may cause personal respect and strengthen the athlete's self esteem. In general, athletes cannot avoid learning what wins and defeats may mean to the individual athlete's identity, without the coach having to stress this fact. Subliminally there is a "latent" chance of teaching values already inherent in these "objective structures".

The central question for pedagogy whether training can educate somebody or not and if it does then how it does so would necessarily become the crucial element of a theory of educating training (6), if the answer is not to be left to mere speculation. Up to now this theory hasn't gone beyond a few scattered starting-points: It is still a real desideratum. What shouldn't be in dispute anymore is the following: Training as a special form of teaching always has to reflect the possibility of an educating training.

\section{FOSTERING AS A MAIN TASK OF TRAINING}

Without doubt training is subordinate to the main purpose of encouragement and fostering. This is the same for both coaches and physical education teachers. The task for both of them is to foster the abilities and skills of their clientele, only that coaches have the "advantage" that their target group attends training on their own free will whereas physical education teachers are confronted with pupils who are forced to attend lessons. It goes without saying that these different initial conditions will necessarily have consequences. Anyway, at this point it is futile to attempt to elaborate on the task of fostering as it is a whole new subject of its own. My aim is now to examine the didactic character of training from another perspective, i.e. from the point of view of fostering, which is an activity that integrates several basic operations. What people intend to foster is talent. But the question that comes to mind directly is: what is talent? The answer lies far beyond the limited number of pages that I have for this article. Therefore allow me a few brief remarks: In the current discussion the opinion gains acceptance that a person's talent cannot be equated with his or her cognitive abilities. Talent is something more complex and differs from what IQ tests profess to measure. A "talent profile" has many more facets to it. As a rule we can start out from a multiple talent which the HARVARD-researcher GARDNER (7) has quite impressively argued in favour of in the last few years. According to him almost all people show signs of a whole ensemble of talents, one of which is the physical talent, which the fostering in the sport training is directed at.

The "better" a coach is able to foster his athlete's talent potential, the more successful he and his athletes will be. Coach and athletes form a community of success, which explains why a coach's success and an athlete's success are mutually dependent. What is more important at the moment: "Good" coaches always are also "good" at fostering talent, i.e. a basis for assessing a coach's quality to a great extent is his competence in developing talents to the full, which is an ability that I want to call the development competence of a coach.

A coach, like any other teacher, always is somebody helping development along. In that there is an indication that a basic activity of fostering is helping somebody. A coach who ist fostering talent helps his athletes to reach the supposed or hoped for talent optimum. He supports them in both word and deed, which also includes the ability to be able to cope with a momentary "performance decrement", a "developmental step backwards" as well as to be able to find the right words after unexpected defeats. In these situations he has to really help out the athletes, if a defeat, which may be a bitter experience for the ones affected, is to be properly "digested". Fostering essentially means supporting somebody, a basic activity that is also part of education (SCHLEIERMACHER). Supporting often is encouraging, which is the epitome of an operation concerning the fostering of talent. Before the fostering of talent comes discovering it. This discovery is based on diagnosing, which often goes along with selecting. Talent selection is a distinguished phrase 
for these activities. The talent scouts who have a good eye for sporting talents are of the greatest importance these days. In the hard business of professional sport where astronomical sums of money are at stake (just think of soccer or tennis) successful scouts are much sought after because with new talents there is always the hope that one day you'll be raking in the money. To be blunt about it, the bodies of these young talents then serve as instruments of capital (ZINNECKER).

Whatsoever: diagnosing of talents connected with anticipating are - together with helping, supporting, encouraging-activities that join together in the act of fostering, around which training is revolving after all.

\section{THE MORAL DIMENSION OF TRAINING}

Teaching ought-as a classic maxim goes-always to be carried out to the best of one's knowledge and belief. You couldn't put the moral relation more succinctly. Not only do teachers have to know something to be able to teach, they also have to act conscientiously, which means that they have to act in a moral way. It would be wrong to believe that the moral dimension is important only in the teaching of values, i.e. only episodically and occasionally. In reality, all teaching has moral foundations - no matter which subject it may be about, a teacher's moral standards are always demanded. The moral behaviour finds its expression in the teaching ethos, which has always played an important part for the pedagogical profession and the theory-forum of which constitutes the pedagogical ethics as a special ethic.

It is quite remarkable that in the young international research of profession a trend is gaining acceptance that evaluates considers this same moral dimension of teaching as a strong factor of teacher professionalism (8), which, however, is necessarily so, as the "professional self", the teacher personality is receiving much attention these days.

This tendency allows a connection to my subject. For: It could be proven repeatedly and beyond a doubt that training is indeed a specific variant of teaching that as such possesses its very own moral quality. The "teacher ethos" corresponds to a "coach ethos", which in another place I have already positioned in detail in the context of trainerethic (9). Trainer ethics is a relatively young ethics, which seems to be getting increasingly important (10), especially because an ethic like that is a crucial constituent of the professionalisation and the professionalism of coaches. The coaches' need for professionalisation consists for the most part in his moral task to watch over the athletes' freedom from harm, over their physical and psychological integrity (11). Coaches act from a position of moral guardians, which is being drawn together and being expressed by the teacher ethos. Accordingly, the quality of their actions is also dependent on their moral behaviour. Coaches necessarily cannot be morally neutral because they have power and therefore are forced to use this power in an appropriate way. As there are all kinds of dangers that coaches may misuse the power attributed to and acquired by them either by manipulating young athletes, by secretly administering drugs to them or by exploiting them in another way- an ethos of this profession must be developed. Similar to the teacher ethos the trainer ethos isn't only related to single parts or areas of a coach's activities but accompanies and backs up all the coach's fields of activity (compare 2) more or less intensively, without one being aware of this moral quality all the time.

How crucial this moral dimension may turn out to be for the professional self of the coach is being reinforced by the impressive, philosophically-inspired, general theory of identity by TAYLOR (12), who is asking after the sources of the self. He considers the moral source to be of a special importance, as it is the source by which many people define themselves and their identity. Why shouldn't coaches do the same?

\section{DISCUSSION}

The considerations above, which had to accept many a shortening and reduction, may stimulate further discussion, which may be devoted to the professionalism of the coaches' actions. If you agree to the argumentation presented in this article, which has emphasised the pedagogical quality of coaching taking teaching as an example, then you might also agree that of future importance will be to discuss the professionalism of coaching from the point of view of pedagogical professionalism. 
The coach's professional self could prove a fruitful/promising starting point for discussion, which could also be useful for finding a connection to international debates about basic research in the field of teacher education. In addition, this course of action would have the advantage of being able to lift the "competence problem" of coaches onto another level of discussion. Close attention would have to be paid to the moral competence, which could take my suggestion of the "hypocratic oath" for coaches as a point of reference (13). It is probably no coincidence that in future professional coaches will have to take an oath at before the Olympic Games, which will then make evident the moral quality of this profession.

\section{BIBLIOGRAPHY}

1. Patsantaras, N. (1994). Trainer als "Sportberuf". Schorndorf: Hofmann.

2. Holz, P. (1985). Trainer was ist das? Leistungssport, 2 (15): 5-14.

3. Meinberg, E. (2001). Trainieren als Unterrichten. In: Jahrespublikation der Zeitschrift Ethik und Unterricht, 47-54.

4. Prange, K. (1986). Bauformen des Unterrichts. Bad Heilbrunn: Klinkhardt.

5. Lenk, H. (1979). Mündiger Athlet und demokratisches Training. In: H. Gabler, H. Eberspächer, E. Hahn, G. Schilling (eds.) Praxis der Psychologie im Leistungssport. Berlin, München, Frankfurt a.M..

6. Meinberg, E. (2001). Trainerethos und Trainerethik. Köln: Strauss.

7. Gardner, H. (1986). Frames of Mind. The Theory of Multiple Intelligences. New York: Basic Books. In German (1991). Stuttgart: Clett-Kotta.

8. Clark, C.M. (1995). Thoughtful teaching. New York: Teachers College Press.

9. Meinberg, E.. (2001). Trainieren als Unterrichten. In: Jahrespublikation der Zeitschrift Ethik und Unterricht, 47-54.

10. Patsantaras, N. (1998). Trainer/Training/Trainerethos. In: O. Grupe, D. Mieth (eds.) Lexikon der Ethik im Sport. Schorndorf: Hofmann, 566-569.

11. Lüsebrink, I. (2001) Trainer/innen und Lehrer/innen Vergleichende Überlegungen zur Professionalisierungsbedürftigkeit. Sportwissenschaft 2 (31) 148-161.

12. Taylor, C. (1996). Sources of the Self. German Translation. Frankfurt a.M.: Suhrkamp.

13. Meinberg, E. (1998). Kinderhochleistungssport wohin? Ein Orientierungsversuch. In: R. Daugs, E. Emrich, C. Igel (eds). Kinder und Jugendliche im Leistungssport: Beiträge des Internationalen Interdisziplinären Symposiums "Kinder Leistungen" vom 7. bis 10. November 1996 in Saarbrücken. Schorndorf: Hofmann, 87-100. 